УДК 94(437.6):728.6

DOI: $10.24144 / 2523-4498.1(44) .2021 .233152$

\title{
TRADITIONAL TIMBER-FRAMED CONSTRUCTION, CASE STUDY: THE RABBI FAMILY HOUSE IN KOROML'A, SLOVAKIA
}

\author{
Mgr. Volovár Maroš \\ $\mathrm{PhD}$ graduant at Department of Theory and History of Architecture, Faculty of Architecture, Czech Technical \\ University in Prague, Czech Republic \\ E-mail: volovmar@fa.cvut.cz \\ https://orcid.org/0000-0001-6307-622X
}

Timber-framed structures are of particular cultural significance. Their wide global and historical occurrence is proved from the oldest prehistory era recorded by archaeological finds to its actual boom in contemporary residential architecture. From ancient times until today, the reasons for their popularity are the low financial costs and fast construction process, and, in some regions, earthquake and flood resistance. The predominance of stone or brick-walled buildings we are surrounded with is relatively recent compared with the historical prevalence of timber structures. In this paper, the traditional construction nature of settlements in the lowland and hilly countryside of the upper Tisa region basin will be illustrated by the example of already a rare residential monument preserved on the eastern edge of Slovakia, close to the current borders with Ukraine, in the former Ung County. Single-storied cellar-less house Nr. 114 in Koroml'a (Sobrance District, Košice Region) has timber-framed construction with post and plank infill, a double-wide floor plan, and six rooms. In addition to the walls' technological uniqueness, the house is the last remembrance of the once considerable Jewish minority of the village and a broader region. The object is relatively recent, built at the end of the 19th century, but represents the characteristic wall construction of the previous centuries in the lowland and hilly countryside of the upper Tisa basin region spreading at the confines of Slovakia, Ukraine, Romania, and Hungary. Last objects with similar wall construction still can be found in some villages of the multicultural region. They are most often in a similar, poor state of decay. However, in three countries, except for Slovakia, several such buildings are registered as architectural monuments or protected in open-air museums.

Keywords: vernacular architecture, traditional timber framing, upper Tisa basin, Slovakia, Jewish minority.

Formulation of the research problem. Wall is a basic element of material classification of traditional buildings. The way of its creation and its spatial arrangement - the construction and layout - are thus the essences of physical identity of structures and the key aspects of their typology. In Slovakian ethnography and historiography of vernacular architecture, a simple twopole idea prevails in scientific discourses, according to which the country is divided into mountain "wooden" area of log cabins and a "clay" area of lowlands - at least that is the practical result embodied in the collection of monuments protected in situ and in open air museums. Constructions that do not fit into this black-and-white division do not enjoy protection or even mere awareness of their existence, and thereafter the hope of preserving their latest examples is slim. A cursory walk through the southeastern Slovak countryside, region target by the small and sketchy interest of Slovakian building ethnography, shows the vagueness of the simplified typology of building materials and the need for its updating.

The purpose of research. The ambition of the research presented in this paper is to pay attention to the historical significance and cross-regional context of traditional timber-framed structures of the upper Tisa region illustrated by the example of building that is technologically and historically unique and unrepeatable, but despite these facts will most probably disappear in the coming years. The study wants to open the discussion on cultural and social value of timber-framed vernacular heritage and draw attention to the need of their acute preservation using positive examples of their monumental and museum protection, especially in Hungary and

\section{Romania.}

In Slovakia and Transcarpathia, the lowland countryside is considered to be a "clay" area and its timberframed constructions are practically noteless, not examined or preserved in open-air museums. In the East Slovakian Lowland two timber-framed peasant houses of linear floor plan (Petrikovce Nr. 41 and Žbince Nr. 45, both in Michalovce District, Košice Region) were listed as monuments since 1987, but due to disinterest of local authorities their preservation was cancelled in 2011 and 2016. Slightly better conditions are in Subcarpathian Region of Ukraine, where intra the Tisa Regional Museum (Затисянський краєзнавчий музей / Tiszaháti Tajmúzeum) in Tysobyken' (Vynohradiv Raion) the oneroomed poor peasant house build in 1918 with probably the pole construction and wattle and daub infill of walls is preserved, and in Vyshkovo (Khust Raion), where the timber-framed house with angle floor plan is conserved as a small local museum (Velyka street Nr. 92). The open-air museums located in the areas of traditional timber-frames as in Humenné (Prešov Region, Vihorlatské múzeum Expozícia l'udovej architektúry a bývania) or Uzhhorod (Закарпатський музей народної архітектури та побуту) collect and present purely log constructions of farther-out mountain areas. Higher attention to the low- an upland timber-framed constructions is put in Romania, where, in its north-west districts, the structures (besides the log ones) can be found in open-air-museums in Negrești-Oaș (Muzeul Satului Oșenesc), Sighetu Marmației (Muzeul Satului Maramureșean) or Baia Mare (Muzeul de Etnografie şi Artă Populară). Relatively ideal are the conditions in Hungary, where the timber-framed 
construction from the north-east parts of the country are richly presented in Budapest-Szentendre national open-air museum (Szabadtéri Néprajzi Múzeum) as well as in local museum of upper Tisa village in Nyíregyháza-Sostó (Sostói Múzeumfalu), where besides other the replica of timber-framed church from Mala Dobron' (Uzhhorod Raion), build in 1784 and abolished in 1820, was reconstructed in late 1970's [Páll, 2009, p. 195].

Analysis of recent research and publications. During the boom of ethnographic and monumental research around the middle of the 20th century, the timberframed constructions were still quite abundant in southern and eastern Slovakia, so the researchers could not fail to meet them. Some researchers touched the objects marginally in their studies. To our days, when the last examples are being irreversibly damaged, no one has dealt with them exclusively.

Probably the oldest short description of a framed structure from the eastern Slovakia can be found in an unpublished research manuscript on traditional crafts in the vicinity of town Michalovce (Košice Region) written by the future significant Czech ethnographer Jitka Staňková. In the part of the manuscript devoted to carpentry she, with the help of carpenter-informant from MichalovceStrán̆any, described the economical and practical circumstances of the craft, local nomenclature of the tools and a brief description and approximate time horizon of construction of the last framed houses with grooved wall filling: "The posts were sunk into the sill plates about one meter apart and planks were inserted between them (planks were bitten out of oak). ... In years $1924-25$, building of whole wooden houses has stopped. Then adobe has come, later the bricks." [Staňková, 1953, pp. 112-124].

Václav Mencl, the most influent Czechoslovakian building historian of the 20th century, put only marginal attention to the east Slovakian framed houses. His monumental monograph on the vernacular architecture of Czechoslovakia contains his own photographs and floor plans of such buildings: one house and a barn from Parchovany (Trebišov District, Košice Region) and one from Sečovská Polianka (Vranov nad Toplou District, Prešov Region), but in the text itself, he approached their construction inconsistently and with contradiction: "In this region, sheds and outbuildings were also timber-framed, ie with a load-bearing frame and a clay or timber infill. Such mixed methods of light construction are encountered in the peripheral zones of all clay areas with a shortage of straight long timber (Ukraine, the Balkans)." [Mencl, 1980, pp. 119-120]. The same construction of the houses, captured by himself quite correctly in his floor plans, was denied in the text for unknown reasons. This attitude may have been influenced by his own map of "a priori" material areas of the vernacular houses in Czechoslovakia with "Danube clay and stone house area" expanded also to the southeastern Slovakia [Mencl, 1980, pp. 570-571].

The authors of the encyclopedia of Czechoslovakian vernacular architecture, Václav Frolec and Josef Vařeka, presented these constructions much more factually. In the headword "drážková konstrukce" (grooved construction), they described it as horizontally placed beams or planks inserted with tapered ends into grooves in posts. [Frolec Vařeka, 1983, p. 36]. They stated it to be supplementary in the Czechoslovakian territory, with the exception of eastern Slovakia, where it was also used in the construction of dwellings, and that it is "one of the oldest documented wooden house constructions", since the end of the 8th century gradually replaced by log cabins, but it continued to survive as confirmed by its multiplying finds from the Middle Ages.

In the years 1976-1978, Marta DudášováPastieriková realized research and documentation of vernacular architecture in south-eastern Slovakia with the aim of selecting objects for the Museum of the Slovak Village in Martin (Žilina Region). Thanks to the relatively large occurrence of framed buildings from the 19th and beginning of the 20th century, her research puts the most complex attention on the given type of construction in Slovakia [Dudášová-Pastieriková, 1984; 1986-a; 1986-b]. While the western part of the solved area - Košice Basin was evaluated as an area of clay construction, the eastern East Slovakian Lowland - was characterized as a "transitional area of wooden and clay construction", where "the construction of residential and farm buildings was processed out of deciduous timber and wicker in combination with mud." She also indicated the horizontal and vertical filling with woven wicker or split laths. She attributed the individual types of filling to the various natural areas of the region and to the various social groups of the rural population. She noted that as such walls were extensively plastered with mud, the region was often mistaken for an area of a clay house. In an extended version of the study [Dudášová-Pastieriková, 1986-a], in addition to the grooved and vattle-and-daub techniques, she mentioned frames filled with adobe too. She pointed out the historicity of building materials in the region, where adobes were more significantly used only from the end of the 19th century, but at the beginning of the 20th century, they were already in strong competition with wood. She reasoned the expansion of clay walls by the loss of timber as well as by fire regulations.

In late 1990's, Košice-Michalovce based National Landscape and Monument Institute elaborated an internal study focused on the "Lower Zemplin" including today's districts of Trebišov, Michalovce and Sobrance. In the introduction to the chapter "Building material and construction techniques", the authors mentioned timberframed buildings too, dividing them without further explanation and hierarchy into "column", "frame" and "woven" techniques. "Column and timbered structures" are also briefly mentioned in the subchapter "Timber house", which, however, is almost wholly devoted to log cabins, extending the research area only on a small norteast edge. The shortcomings of the modest text are replaced by a rich pictorial appendix. This is the document, where, for the first time, we can find several images of the exterior and interior, as well as a schematic floor plan of the frame house No. 114 in Koroml'a. The researchers have visited the house still inhabited by the last member of the family (fig. 4a), but, however, they did not state any added information about the origin, development, history of repairs, way of living in the house and history of the family [Čurmová - Gal'ová 1998, unpaginated].

Areal distribution and development of the construction. Most of the East Slovakian framed buildings, preserved or documented by previous researchers, were built around the turn of the 19th and 20th 
centuries. Their endurance rarely exceeded the lives of two generations, therefore, the older examples have not been preserved. The oldest documented peasant house comes from 1836 (Čel'ovce, Trebišov District) [Dudášová, 1986b, pp. 113-114] and was demolished i 1990's. Few of younger, last timber-framed houses can still be found in the villages of East Slovakian plain, East Slovakian hills and on the both side foothills of the Vihorlat and Slanské ridges. According to Ján Lazorík, the northernmost areas of their occurrence are the surroundings of Prešov (central Šriš) and the valley of the river Cirocha between Snina and Humenné. [Lazorík, 2002, pp. 98-99]. North of these is the area of log cabins, where the framed constructions are only supplemental, occasionally used on smaller farm buildings [Sopoliga, 1998, p. 321]. In the southernmost part of the East Slovakian lowland - in the region of Medzibodrožie (hung. Bodrogköz), south of the river Latorica - the timber-framed houses were evidenced by cartographic and statistical records on the turn of the 19th and 20th centuries, but soon fully eliminated by expansion of adobe and volcanic stone easy mined by the town of Král'ovský Chlmec.

According to the foregone dominant occurrence of the construction type in question in many lowland and hilly parts of Upper Tisa basin, we assume their local continuous development and connection with the oldest, prehistoric timbered houses with a rectangular floor plan and pole construction of the walls. Pole houses with the loadbearing vertical poles sunk into the terrain and wattle an daub infill walls are known since Neolithic. The oldest evidence of similar objects in south-eastern Slovakia come from the Eneolithic Tiszapolgár culture (3300-3100 BC) and were found in Lúčky-Viničky (Michalovce District) [Šiška, 1968, pp. 130-131, fig. 31-33]. Even in post-war period, several peasant houses of similar construction, build in 19th and 20th century, were preserved in southwestern Slovakia [Mjartán, 1963]. In Hungary, several of such houses were saved for open-air museums, such as the house with a ridge beam construction of the roof from 1803 from Bükkaranyos (Miskolc District) [Bálint, 2010]. In the south-eastern Slovakia, one of the last archaic pole object - a large sheep cot - was photographed in the mid-1970's [Volovár, 2016, fig. 3].

Compared to the archaic pole types, the last surviving Upper-Tisa framed constructions are more advanced in structure: vertical load-bearing elements of their walls - the posts - are not sunk into terrain, but mortised to the sill plate mounted on a simple stone base or masonry. This improvement protects the building from the earth's moisture, but requires the more advanced shaping of the elements and joints, in addition, the frame must be diagonally braced. The solution connects our constructions with the better known timber-framed (Fachwerk) monuments of the Western and South-Eastern Europe areas of the former provinces of Roman Empire, where the construction was well known too [Adam, 2005, pp. 236242, 407]. To the Upper Tisa basin area, it was most probably brought by German colonists after the Tartar invasion in the 13th century. The hypothesis is supported by the German nomenclature of some structural elements, as: "švel'a" (sill plate), "burt" (post), "fuga" or "kamp" (groove), "bant" (brace and collar tie) or "platva" (wall plate ) [Volovár, 2016, fig. 1]. In the East-Slovakian fortified towns, economically developed with contribution of the German colonists, the half-timbered structures are well documented. In Košice it is, inter alia, archaeological find of lower parts of a frame house from the 14th century [Rusnák, 2012]. Veduta of Košice, issued in 1617, shows numerous timber-framed houses in the suburbs of the town. However, German colonists settled not only in free royal towns, but also in small manor towns and villages, where they have assimilated with the old settlers with times. In Koroml'a (Sobrance District), where we will focus thereinafter, guests, settled in terms of German law, are evidenced already before Wallachian colonisation. Not far of Koroml'a, the old German settlers are assumed in Vyšné and Nižné Nemecké [Rábik, 2006, p. 339, 430]

Presentation of the research basic material. Koroml'a lies in the East Slovakian Hills at the western foot of Poprichniy Ridge, which is part of the inner-Carpathian Vihorlat-Gutin Volcanic Ridge. The village has doublerow pattern, spread at the sides of Koromliansky stream, in the height of 250-320 m above the sea. The rural zone of the village stretches up to the mountain ridge and in most of the territory is covered with deciduous forest. It is assumed that the first inhabitants of the village were lumberjacks, coal miners and shepherds, as the subject of the first mention of the site in 1337 are the Wallachians ("olahos") settled here [Uličný, 1995, p. 121]. In 1899, the village was introduced into the sphere of scientific research by Norwegian Slavicist Olaf Broch who analysed its unique dialect [Broch, 1899].

The oldest evidence of the structural character of the village is a cadastral map from 1863, when the timber (yellow) buildings dominated here. Only the church and the mill were walled (red) (fig. 1). In 1900, according to statistics, Koroml'a had 680 inhabitants, mostly Greek Catholics, 72 citizens declared the Jewish religion. The village had 91 houses, 83 of them were built of timber and 8 walled of stone or brick. All the coverings were flammable: 70 houses were covered with straw and 21 with shingles [MSK, 1902, pp. 260-261]. In 1910, Koroml'a had 636 inhabitants, 78 of them declared Israeli confession. There were 106 houses, already 16 of them walled of stone or brick and 90 built of timber. 12 houses were covered with fireproof materials, 30 with shingles and 64 with straw. [MSK, 1912, pp. 260-261]. Today, the object in question is one of the last four timber houses remaining in the village, the youngest one ( $\mathrm{Nr}$. 157) was built cca in 1936.

According to local informants, family of the Jewish rabbi Simon Gubner lived in the house Nr. 114 before the 2nd World War. With his wife they had two daughters and ten sons, living largely with their own families outside Koromla. Only four sons survived the war and the Holocaust. One of them, Adolf "Abram" Gubner (1905 October 14, 1998), has returned to Koroml'a and was the last inhabitant of the house. Since the village fell to Hungary in 1938, Mr. Gubner was enlisted in its army. However, he went into Russian captivity at the front, thus saved himself from deportation and spent six years in a captive camp. After returning, he has lived in his parents' house as an old bachelor until 1998 (fig. 4a). According to local informants, after the war, the house was property of his brother Ján Gubner and his daughter, who lived in Canada. Today, the cadastral portal lists the owners Marek 
Gubner (1/3) and Jozef Gubner (2/3) living in Montreal. Koromla municipal government missed out in contacting them, therefore the house cannot be repaired or maintained and decays since 1998.

The house is a timber-framed variation of the floor plan design, relatively common in the 18th-19th centuries and exemplified in the wider region by the walled dwellings of the lower nobility, rural and small-town elites, parishes, schools or pubs. The floor plan can be explained as traditional linear three-space house developed in transverse direction; analogous to linear floor plan there is an entrance hall with kitchen in the central bay and the side residential rooms accessible from the hall. Hall and the side rooms are supplemented with kitchen and chambers in transverse direction. The log-cabin version of the plan can be found in the Uzhhorod open-air museum presented by pub from Verkhniy Bystryy (Mukachevo Raion) from the late 1860 's. Only in the 1960's, the double-wide floor plan has widely spread in the upper Tisa region village houses, walled out of adobe, brick or cinder-concrete blocks.

The house stands in a left-bank side, above the centre of the village at a height of $290 \mathrm{~m}$ above sea. It faces the shorter, north side towards the street (fig. 2a, 4b). The house is cca $7.5 \mathrm{~m}$ wide and $15.3 \mathrm{~m}$ long, ground, without a basement, the roof has upper third-hipped gables (fig. 2).

On the sketch to the cadastral map from 1863, there is no regular development in its vicinity and the house is still not recorded. The clean copy of the map contains updates marked with a red line in 1918, when the boundaries of the plots were adjusted to today's shape and the house with current Nr. 114 appears (fig. 1). Building of the house between $1863-1918$, according to the maps, was confirmed by dendrochronological research, which proved that the structural elements are made of oak wood cut at the turn of 1890/91 and 1891/92 and so the house, usually carved from fresh wood, was probably built in the years $1891-1892$. Dendrochronological research was realised by Ing. Tomáš Kyncl on the 31/7/2019.

Today, the house is one of the last timber-framed buildings with the double-wide floor plan in region, but at the end of the 19th century, its width did not stand out even in Koroml'a. On the mentioned sketch of the cadastral map from 1863, which also states the widths of the objects, there are many similar and even wider timber buildings: Christian and Jewish schools standing on the square (latter one was probably also a synagogue), a Greek Catholic rectory, as well as several residential houses along the street. The oldest remaining houses of the village exemplify that those unpreserved buildings could be of timber-framed structure too.

Description of the structure (fig. 3): Sill plates of the load bearing frame lie on low base wall built of fieldstones and mud. In the corners, the plates are linked by cross lap joints. Today, the base and part of the sills are largely sunk down under the rising terrain. Posts (width 15-20 cm, height $217 \mathrm{~cm}$ ) have tenon on each end and are plugged into mortises cut into the sills and wall plates. The posts have grooves assigned for inserting of the wall infill consisting from vertical planks - "palanki" - made of halved logs with tapered ends. Some grooves of posts are slightly open in upper end due to the insertion of the last planks. In the corners of the rooms the load bearing frame is solidified by diagonal braces (width $10 \times 10 \mathrm{~cm}$, length cca $150 \mathrm{~cm}$ ). The braces are linked to the posts and plates by $5 \mathrm{~cm}$ embedded lap joints and secured with wrought nails. The window openings are bounded by horizontal rails mortised into grooves of the posts and by small posts mortised into rails. The walls, including the posts, are plastered with daub and were periodically whitened. Because of cohesion with the mud plaster, the posts are roughened with the axe cuts.

Ceiling beams are anchored to the wall plates by single cogged joints. The ceiling beams jut-out over the width of the house and serve as the tie beams simultaneously. The rafters are anchored into the beams with angled tenon and mortise joints. At the roof ridge, the rafters are linked by open mortise and tenon joints and secured by wooden pins. Collar ties are linked with rafters by angled through-lapped joints secured with wooden pins too. The lathing is made of industrially processed laths (3 $\times 5 \mathrm{~cm}$ ) and carries a sheet metal covering. Probably the shingles preceded the sheet, but there are no remains of them on the loft.

Four rooms of the house were heated. In the front room of the front bay, a rectangular metal sheet on the floor and a smoke opening in the eastern corner indicates the unpreserved oven or stove, mouthed across the partition wall into adobe chimney in the western corner of the kitchen (fig. 6). On the loft, it is fed to the main wide chimney above the south wall of the kitchen (fig. 5). Latter is also built of adobe, only an unpreserved section above the covering was made of brick. In the kitchen, the stove was walled left to the main chimney. The bread and maces oven was walled in the rear room of the rear bay and mouthed also across the partition wall into the chimney, stoked from the kitchen through the chimney base. The front room of the rear bay could have a cast-iron stove, mouthed across the two partition walls into the same chimney in the kitchen.

The floors are mostly earthen, only in the front room of the front bay the basements of the wooden floor have been preserved. Interior door wings as well as all the furniture and also the parts of the timber construction of the rear bay are lost.

Research conclusions. Last examples of vernacular timber-framed constructions, once dominating in southeast-Slovakian villages and small towns, are decaying irretrievably. The objects miss any monumental preservation as well as involvement of the municipalities and their entire disappearance is question of upcoming years. In case of Koroml'a rabbi house, the decay of the object could be stopped only by the improbable interaction of its abroad owners - probably not even knowing about their heirship - or by the radical expropriation at the hand of the state and the subsequent investment in its restoration. The loss of the house will cause the irreversible damage to the material cultural heritage of Slovakia as well as to the transnational macro-region of Upper Tisa basin crossing the state borders. 
Acknowledgement

The research is promoted with grant of Czech Technical University in Prague, SGS19/195/OHK1/3T/15, Survey and Documentarion of Traditional Timber Frame Buildings in Upper Tisa Basin.

\title{
References
}

Adam, Jean-Pierre, 2005. Roman Building. Materials and Techniques, London - New York, 727 p. (in English).

Bálint, János, 2010. Egy bükkaranyosi lakóház bontása [Demolition of a dwelling house from Bükkaranyos], Ház és ember, A Szabadtéri Néprajzi Múzeum Évkönyve 22, Szentendre, pp. 67-88. (in Hungarian).

Broch, Olaf, 1899. Weitere Studien von der slovakisch-kleinrussichen Sprachgrenze im östlichen Ungarn. Videnskabsselskabets Historisk-filosofiske Klasse, No. 1 [Second study on the Slovak-Little Russian language border in eastern Hungary. HistoricalPhilosophical Class of the Science Society, Nr. 1], Kristiania, 104 p. (in German).

Čurmová, Viera - Galová, Anna, eds., 1998. Dolný Zemplín [Lower Zemplin]. Košice - Bratislava - Michalovce, unpaginated document (in Slovak). Deposit: Regional Monumental Office in Košice, sign. T-63. (in Slovak).

Dudášová, Marta, 1984. L’udové stavitel'stvo a jeho lokálne dobové formy na juhovýchodnom Slovensku [Vernacular architecture and its local forms in south-eastern Slovakia], Národopisné aktuality 21, Nr. 1, pp. 9-18. (in Slovak).

Dudášová, Marta, 1986-a. Charakter l'udového stavitel'stva a spôsob života na juhovýchodnom Slovensku [Character of the vernacular architecture and way of living in south-eastern Slovakia], Zborník SNM LXXX, Etnografia 27, pp. 47-95. (in Slovak).

Dudášová, Marta, 1986-b. Výber objektov l’udového stavitel'stva z regiónu juhovýchodné Slovensko pre Múzeum slovenskej dediny [Selection of the object of vernacular architecture from region of south-eastern Slovakia for Museum of Slovak village], Zbornik SNM LXXX, Etnografia 27, pp. 97-118. (in Slovak).

Frolec, Václav - Vařeka, Josef, 1983. Lidová architektura. Encyklopedie [Vernacular architecture. Encyclopedia], Praha Bratislava, 360 p. (in Czech).

Lazorík, Ján, 2002. Fotočitanka l’udovej architektúry a bývania východného Slovenska [Photo-reading-book of vernacular architecture and habitation in East Slovakia], Prešov, 178 p. (in Slovak).

Mencl, Václav, 1980. Lidová architektura v Československu [Vernacular architecture in Czechoslovakia], Praha, 632 p. (in Czech).

Mjartán, Ján, 1963. Posledné sochové domy na južnom Slovensku [Last houses with ridge-beam bearing construction in South Slovakia], Ludové stavitel'stvo a bývanie na Slovensku. Sbornik štúdii [Vernacular architecture and habitation in Slovakia, Review book], Bratislava, pp. 89-134. (in Slovak).

MSK, 1902. Magyar statisztikai közlemények, 1. kötet, 1900. évi, Népszámlálása [Hungarian Statistical Bulletins, volume 1, 1900, Census]. Budapest, 610 p. (in Hungarian).

MSK, 2012. Magyar statisztikai közlemények, 42. kötet, 1910. évi, Népszámlálása [Hungarian Statistical Bulletins, volume 42, 1910, Census], Budapest, 994 p. (in Hungarian).

Páll, István, 2009. „Ahol visszafordul az idő kereke...“ Gondolatok a 30 éve megnyílt Sóstói Múzeumfaluról ["Where the wheels of time are turned back..." Thoughts about the Museum Village Sóstó, which opened 30 years ago], Ház és ember, A Szabadtéri Néprajzi Múzeum Évkönyve 21, Szentendre, pp. 189-218. (in Hungarian).

Rábik, Vladimír, 2006. Nemecké osídlenie na území východného Slovenska v stredoveku (Šarišská župa a slovenské časti žúp Abovskej, Zemplínskej a Užskej) [German settlement on area of East Slovakia in middle ages (Šariš County and Slovakian parts of Abov, Zemplin and Ung Counties], Bratislava, 434 p. (in Slovak).

Rusnák, Rastislav, 2012. K charakteru stredovekej drevenej zástavby na košických parcelách [On the nature of medieval timber build-up of Košice plots], Archaeologia historica 37/1, pp. 87-100. (in Slovak).

Sopoliga, Miroslav, 1998. Severovýchodné Slovensko [North-East Slovakia], Ludová architektúra a urbanizmus vidieckych sídiel na Slovensku [Vernacular architecture and urbanism if the village settlements in Slovakia], Bratislava, pp. 317-345. (in Slovak).

Staňková, Jitka, 1953. Pol’nohospodárstvo, vinohradníctvo, výroba, bývanie. Budkovce, Michalovce, Vinné, Vel'ké Zalužice, okr. Michalovce [Agriculture, viticulture, crafts, housing. Budkovce, Michalovce, Vinné, Vel'ké Zalužice, Michalovce District] 385 p. (in Czech). Document, deposit: Ethnological Institute of Slovak Academy of Science, Bratislava, add nr. T. A. 142.

Šiška, Stanislav, 1968. Tiszapolgárska kultúra na Slovensku [Tiszapolgár culture in Slovakia], Slovenská archeológia XVI, Nr. 1, pp. 61-175. (in Slovak).

Uličný, Ferdinand, 1995. Dejiny osídlenia Užskej župy [History of settlement of Ung County], Prešov, 355 p. (in Slovak).

Volovár, Maroš, 2016. Drevený skelet v stavebnej tradícii východného Slovenska [Timber frame in building tradition of eastern Slovakia], Déjiny staveb 2016, Plzeň, pp. 289-304. (in Slovak).

Село КОРУМЛЯ, по угорски КОRUMLYА, бъ Угорщчины, жупа Ужанская, 1863 [Village of Koroml'a, in Hungarian Korumlya, in Hungary, Ung County, 1863]. Map, deposit: Geodetic and Cartographic Institute in Bratislava, add nr. Už 88.

\section{SUMMARY}

\section{ТРАДИЦІЙНЕ КАРКАСНЕ БУДІВНИЦТВО НА ПРИКЛАДІ ЖИТЛА РОДИНИ РАБИНА ІЗ С. КОРОМЛЯ, СЛОВАЧЧИНА}

\author{
Мгр. Марош Воловар \\ докторант кафедри теорії та історії архітектури, архітектурний факультет, Чеський технічний університет \\ в Празі, Чехія
}

Дерев'яні каркасні конструкції мають особливе культурне значення. Про це свідчать їх глобальне розширення та історичні докази від найдавнішої доісторії в археологічних знахідках до надзвичайного розширення в сучасному житловому будівництві. 3 незапам'ятних часів донині причиною їх популярності $\epsilon$ низькі витрати на будівництво та швидкий проиес спорудження, а також, наприклад, стійкість до землетрусів та паводків. Порівняно з історичним поширенням дерев'яних конструкиій, переважання кам'яних або цฺегляних 
стін, щео оточують нас, є відносно молодим. У иій статті традиційне каркасне будівництво буде представлене на прикладі одного, сьогодні дуже рідкісного житлового пам'ятника, щуо зберігся в східному краї Словаччини, біля кордону з Украӥною, в колишній Ужанській жупі. Одноповерховий будинок без погребу Nr. 114 у Коромлі (район Собранце, Кошицький регіон) має каркасну конструкцію з канавками у колонах та заповненням із напівколоди, вдвічі широкий план поверху і містить шість кімнат. Окрім унікальності технологї стін, будинок є останнім пам'ятником колись чисельної єврейської меншини в селі та в регіоні. Будівля відносно молода, побудована наприкіниі ХІХ століття, але демонструє характерну будівельну структуру останніх століть у низинному та гористому ландшафті Верхнього Потисся - на кордонах Словаччини, Украӥни, Румунї та Угорщини. Будівлі з подібною стіновою структурою все ще можна знайти в деяких селах макрорегіону. Вони найчастіше перебувають у подібному, поганому стані занепаду, але у трьох згаданих країнах, за винятком Словаччини, кілька таких будівель охороняються як пам'ятки або зберігаються в музеї просто неба.

Ключові слова: народна архітектура, каркасна конструкція, Верхнє Потисся, Словаччина, єврейська меншина. 


\section{ILLUSTRATIONS}

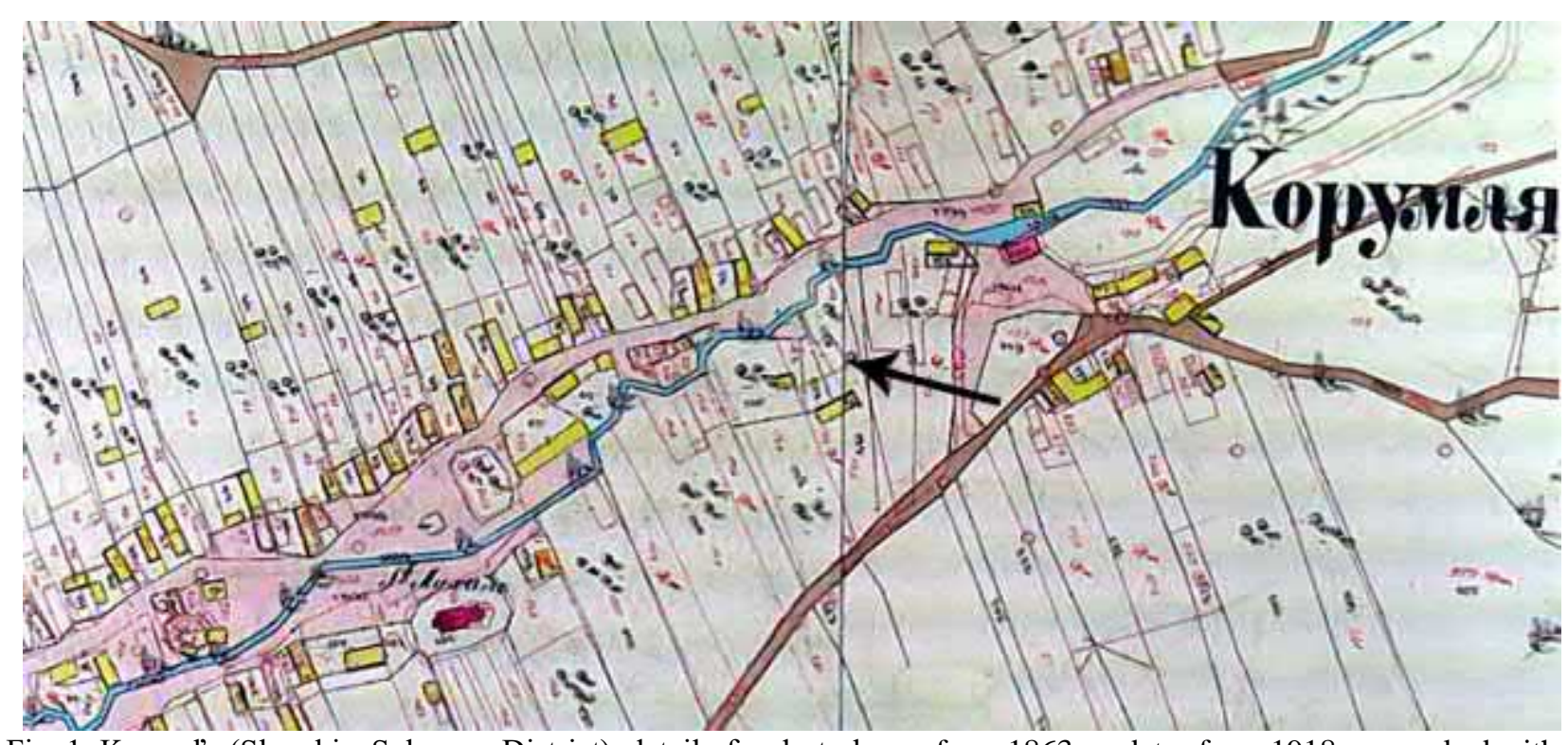

Fig. 1: Koroml'a (Slovakia, Sobrance District), detail of cadastral map from 1863, updates from 1918 are marked with red line (source: Geodetic and Cartographic Institute Bratislava, add nr. Už 88).

Fig. 2: Koroml'a (Slovakia, Sobrance District), Nr. 114, graphic documentation: a - North-east elevation, street facade; $\mathbf{b}$ - Transverse section; $\mathbf{c}-$ Ground plan; d-South-west elevation, court facade. Right side of roof is looking apart from covering; $\mathbf{e}$ - Longitudinal section.

Timber elements: B - brace; CT - collar tie; CB - ceiling beam (in the case, identical with tie beam); $\mathbf{I}$ - infill (in the case the halved $\operatorname{logs}$ ); $\mathbf{P}$ post; $\mathbf{R f}$ - rafter; $\mathbf{R}$ - rail; $\mathbf{S P}$ - sill plate; $\mathbf{W P}$ - wall plate (measuring and drawing by $\mathbf{M}$. Volovár).
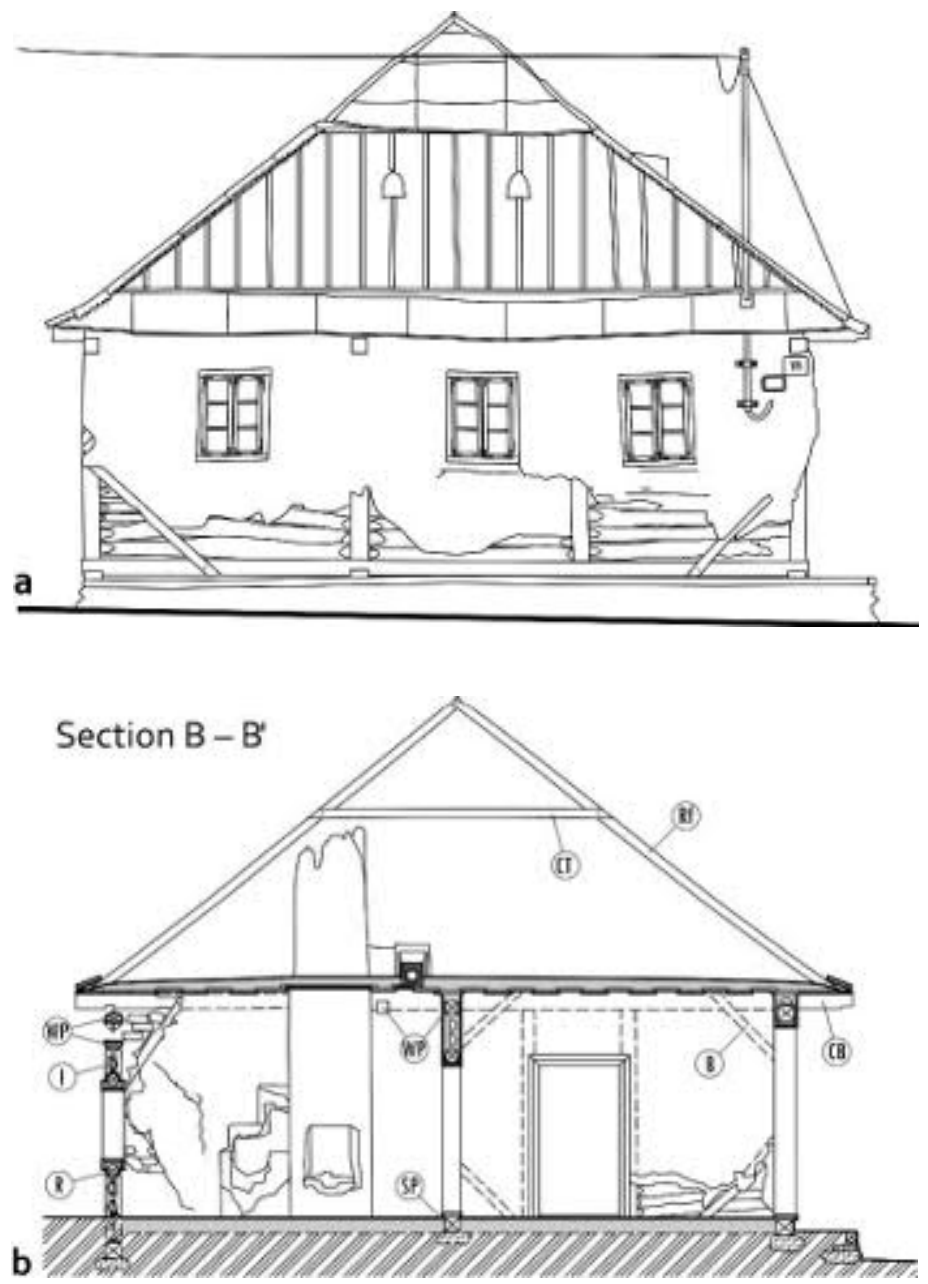

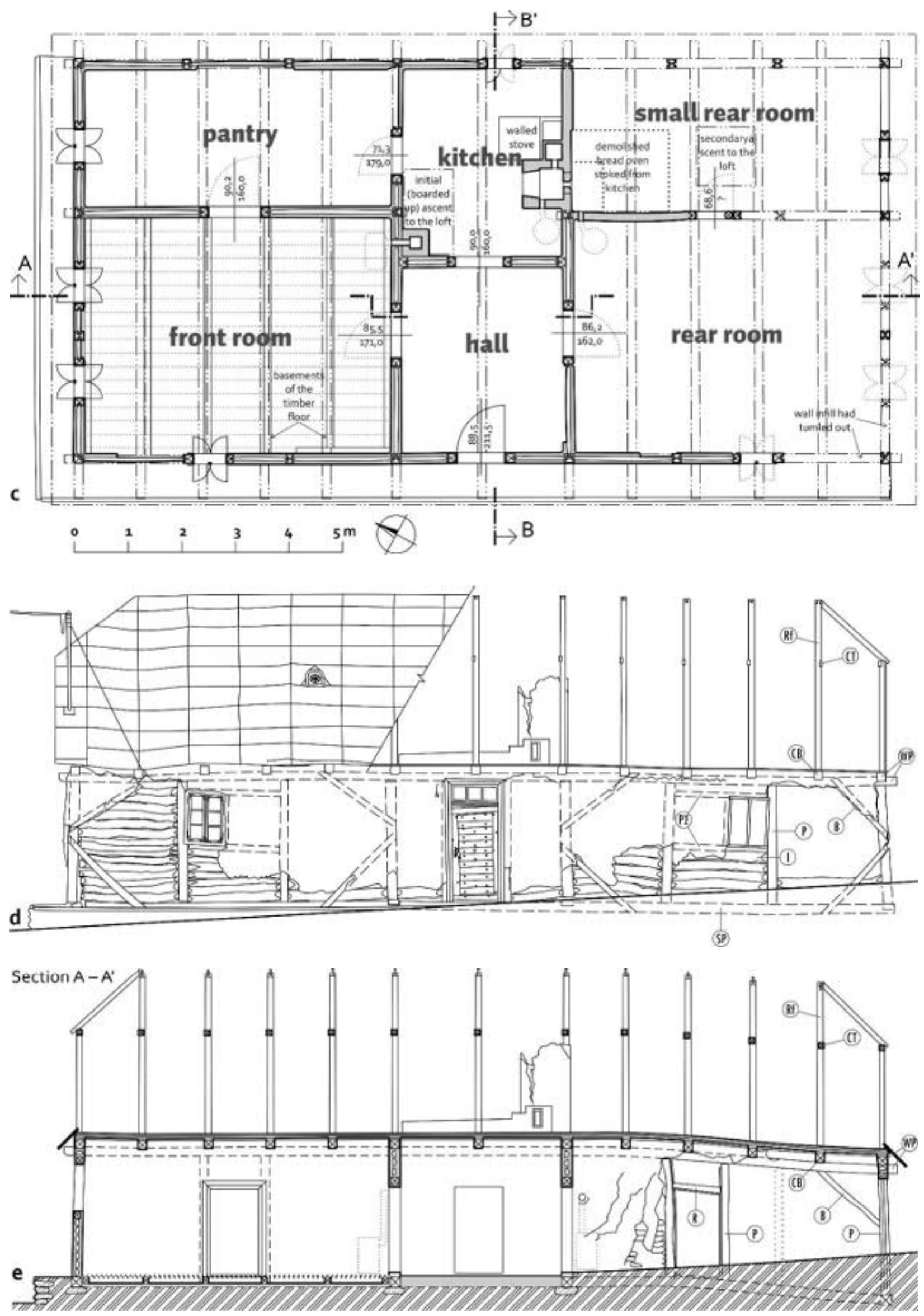

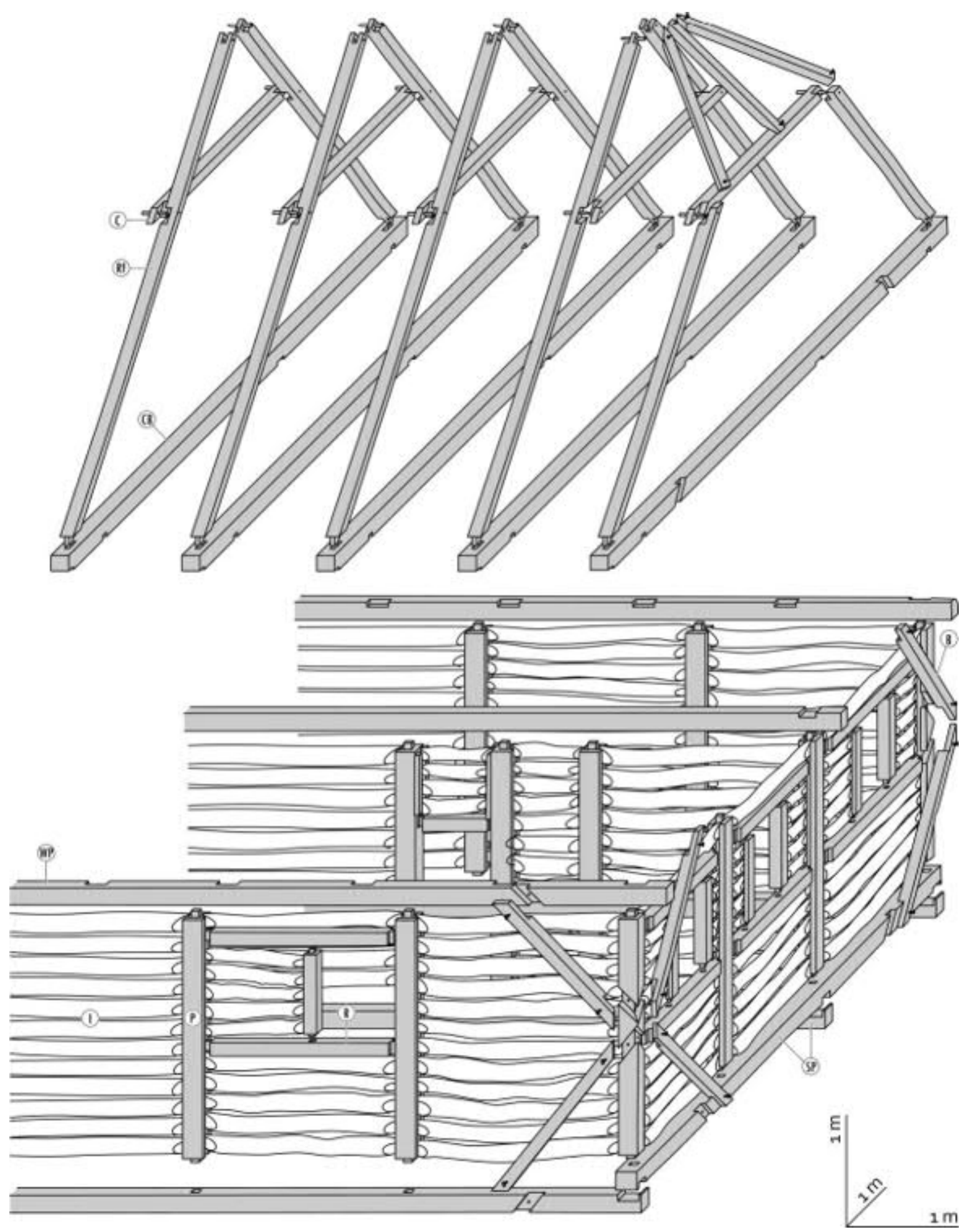

Fig. 3: Koroml'a (Slovakia, Sobrance District), Nr. 114, rear bay of the house in cabinet oblique projection. Configuration of the timber elements. For the shortcuts see legend of the fig. 2 (drawing by M. Volovár). 

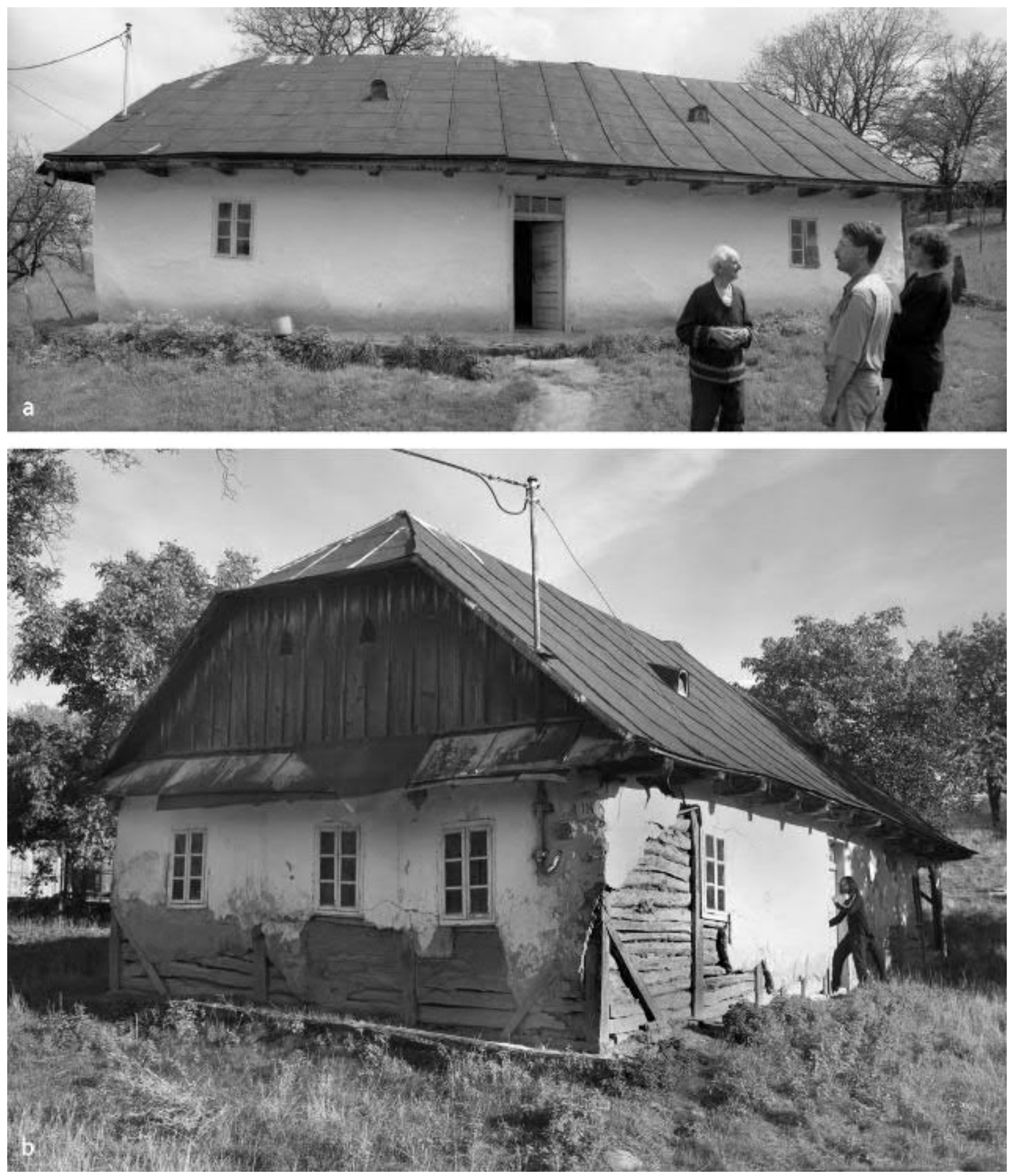

Fig. 4: Koroml'a (Slovakia, Sobrance District), Nr. 114: a - Court facade in 1997. With his back to the house stands the last inhabitant Adolf "Abram" Gubner (photo by V. Sinčáková, 1997); b - North east corner of the house facing the street (photo by M. Volovár, 2013). 


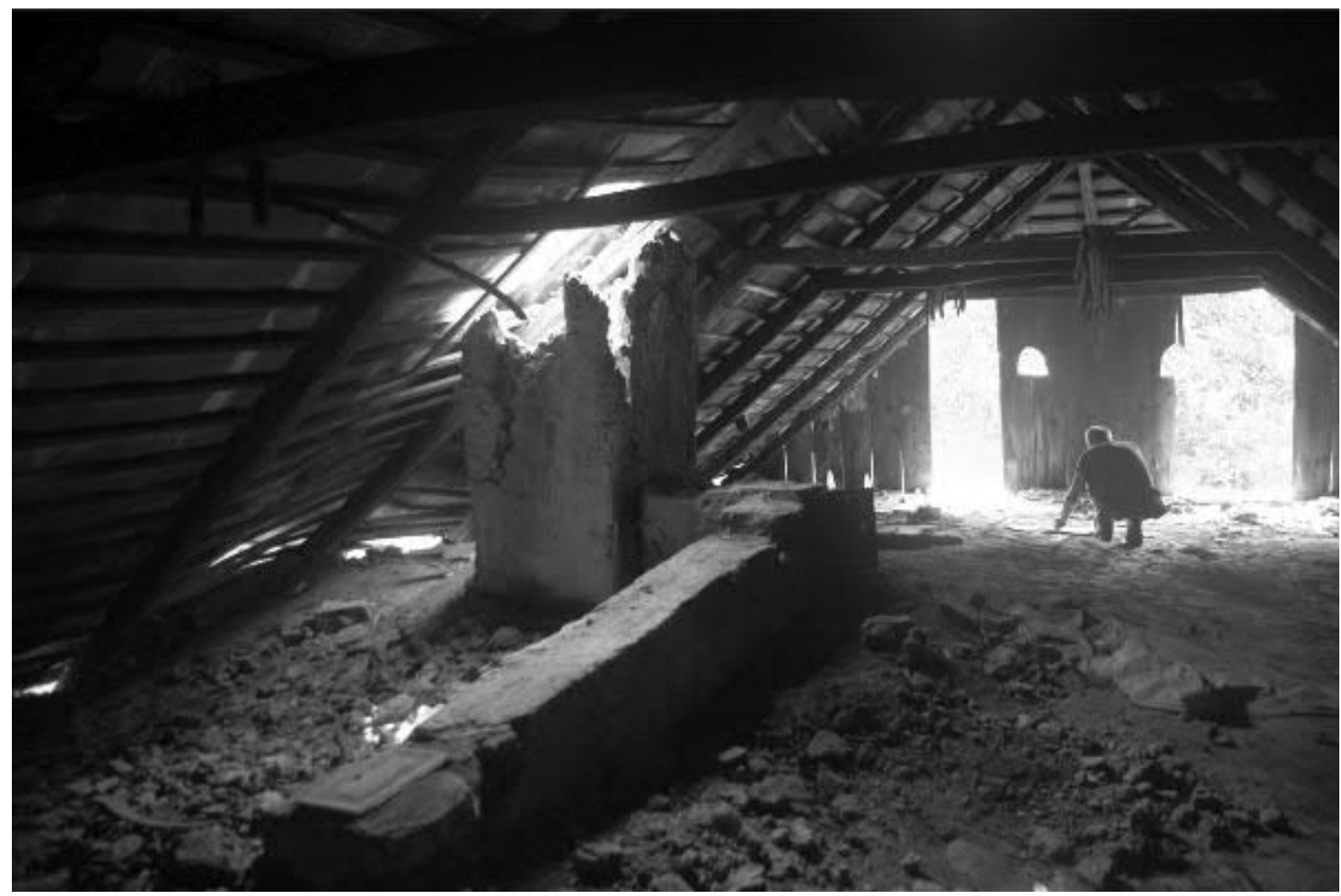

Fig. 5: Koroml'a (Slovakia, Sobrance District), Nr. 114, the loft with the smoke shaft and chimney (photo by M. Volovár 2018).
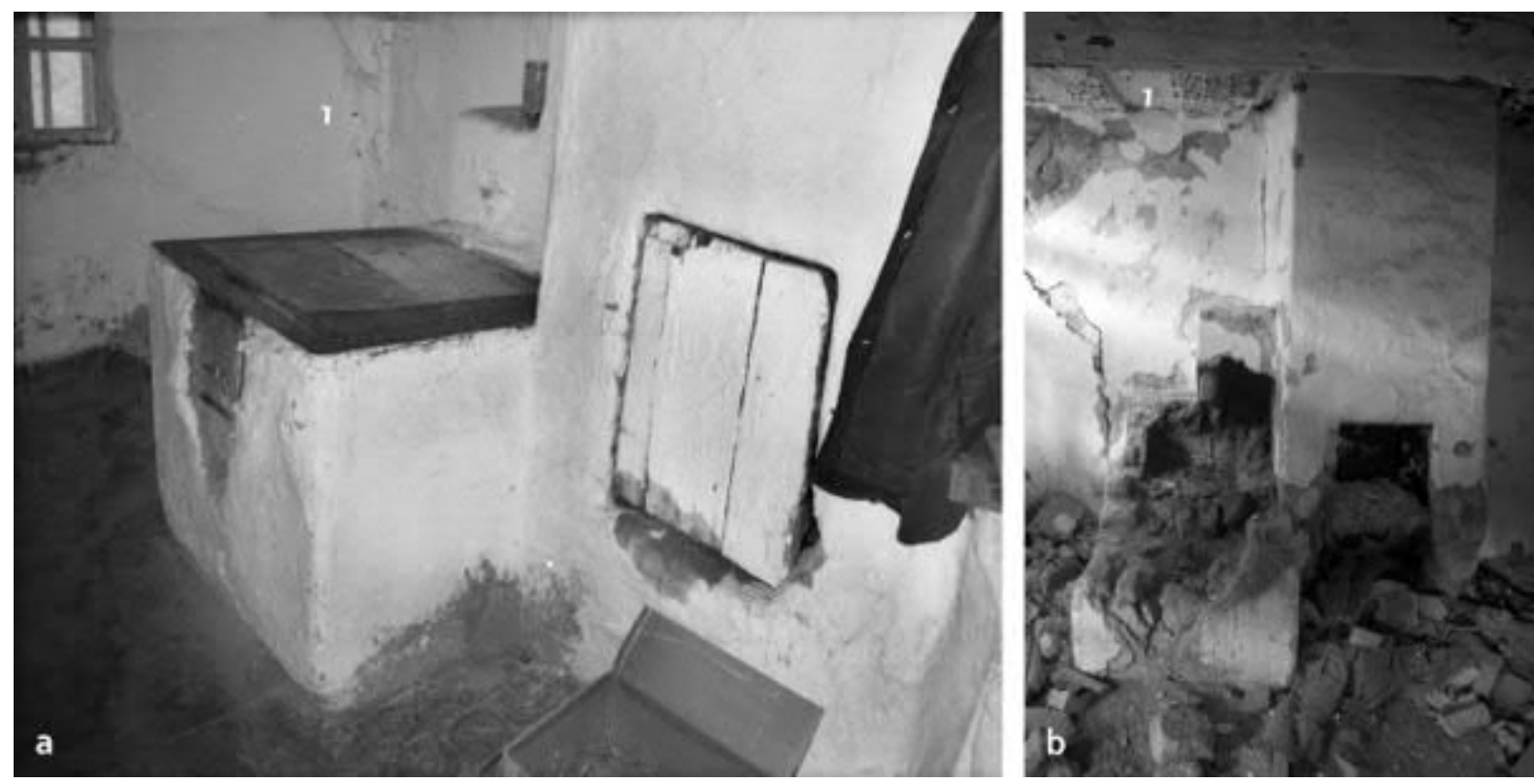

Fig. 6: Koroml'a (Slovakia, Sobrance District), Nr. 114, walled stove and chimney in the kitchen: a - State in 1997 (photo by V. Sinčáková); b - State in 2018 (photo by M. Volovár). 


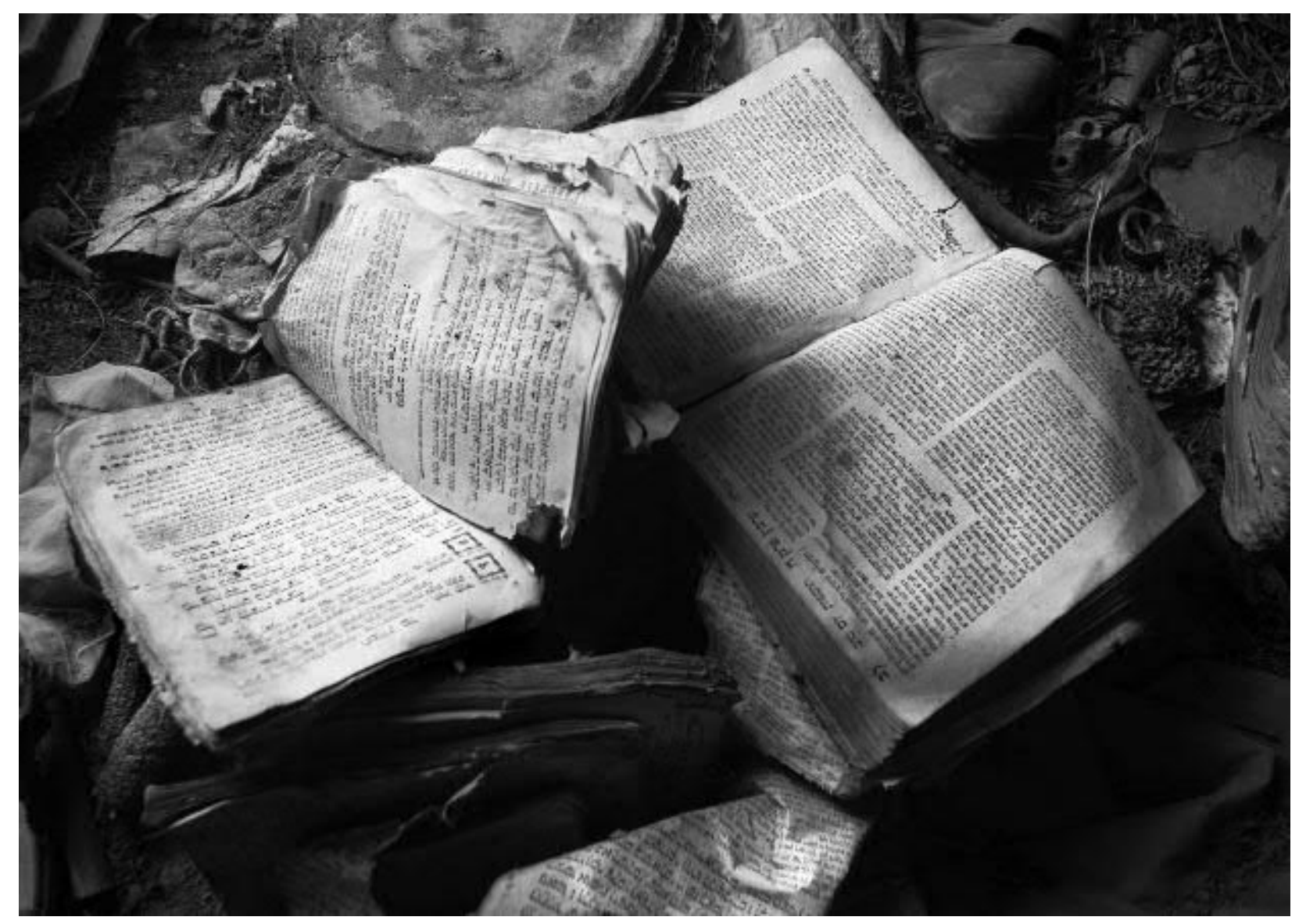

Fig. 7: Koromla (Slovakia, Sobrance District), Nr. 114, books in Hebrew in the loft (photo by M. Volovár 2018). 